\title{
HUMAN RESOURCES FACTORS AFFECTING INCREASING LABOR PRODUCTIVITY IN CONSTRUCTION PROJECTS IN EAST NUSA TENGGARA
}

\author{
Alva Yuventus Lukas ${ }^{1}$, Jusuf Wilson Meynerd Rafael ${ }^{2}$ \\ ${ }^{1}$ Civil Engineering Department, Politeknik Negeri Kupang, Kupang, 85228, Indonesia \\ ${ }^{2}$ Civil Engineering Department, Politeknik Negeri Kupang, Kupang, 85228, Indonesia \\ Email: alva_ajl@yahoo.co.id
}

\begin{abstract}
The purpose of this study is to determine the resource management factors that affect labor productivity as well as the dominant factors, with research sites on construction projects in eastern Indonesia, particularly in East Nusa Tenggara. This research is aimed at construction workers, such as masons, chief craftsmen, foremen, and workers. This study uses a survey method. Primary data were collected through a questionnaire, then formulated and processed. Data processing in the form of respondents' opinions and attitudes towards problems that exist in construction projects related to productivity, data analysis techniques use factor analysis methods and multiple linear regression analysis with the SPSS statistical program. Results of processing and discussion of data, it is found that: (A) Human Resource Management Factors that affect Labor Productivity in several construction projects in East Nusa Tenggara are About Age, X1, about Work Experience, X2, Level of Education, X3, about Wages, X4, Total Family Count, X5, Working Health and Safety, X6, Relationship Workers, X7, about Managerial, X8, and about Influential Motivations, X9, together form the equation $Y=12,776$ $-0,217 . X 1+0,151 \cdot X 2-0,087 . X 3-0,074 . X 4-0,263 . X 5-0,468 X 6-0,058 . X 7+0,129 . X 8+$ $0,384 . X 9$. (B) The dominant factors affecting respectively are the Occupational Health \& Safety of Workers, X6, Subject to the Number of Dependents in the Family, X5, and Subjects of Motivation, X9.
\end{abstract}

Keywords: Human Resource Management, Ranking, Construction Project.

\section{Introduction.}

\subsection{Research Background.}

The development that has been carried out by the Indonesian people since the beginning of independence until now, cannot be separated from the efforts to develop infrastructure on an ongoing basis. As one of the indicators in development, the construction sector plays an important and strategic role in national development, considering that this sector produces the final product in the form of buildings both in the form of facilities and infrastructure which function to support the growth and development of various sectors. Taufik 2012, stated that construction is an economic sector that is very important to produce a building product both in its function as infrastructure and property, as well as a significant contributor to Gross Domestic Product (GDP). The Central Statistics Agency (2016) states that the Construction Business Field Performance in the first quarter of 2016 compared to the first quarter of 2015 has increased by 7,87 percent. The growth of this sector is supported by the execution and realization of government projects both through the State Budget and State-Owned Enterprises and cooperation between the government and the private sector. In addition, the 
Indonesian Central Statistics Agency released that the 5 main contributing sectors to Gross Domestic Product (GDP) in 2016 in the fourth place were the construction sector at 10,42\%.

The construction industry sector is closely related to infrastructure development, as shown by the data above that the construction industry sector has driven the real economy and has contributed to the country's economic growth, through infrastructure development, many other economic sectors have participated in supporting state revenues. In addition, it is inevitable that infrastructure development has also absorbed a large number of workers, thus companies operating in the construction sector need to increase their competitive advantage from their internal resources in order to compete with other construction companies.

Increasing the competitive advantage of internal resources in the company is an inevitable necessity, so a minimum of 4 qualities is needed, namely (1) quality in terms of adding value to the company, (2) having unique and rare qualities, (3) quality which is difficult to imitate by competitors or competitors, (4) the only quality or produce an irreplaceable final product. Internal resources that can meet these demands are Human Resources (Smook \& Tong, in Ervianto, 2002). Novianti, 2013 states that to support the existence of good infrastructure, it is important for a company engaged in the construction sector to have and increase the capacity (skills) of internal resources, one of which is the human resources used.

Human resources are an important factor in determining the survival of a company even though a company has complete facilities and infrastructure, without the support of good moral, dynamic, disciplined and unified human resources, the company's survival will run slowly, even if it doesn't last long. (Nasron \& Astuti, 2011). During 2011, of the 5,7 million construction workers, only 10 percent were categorized as reliable. Meanwhile, 30 percent are categorized as sufficiently skilled and 60 percent are not skilled, aka manual labor. When viewed from education, only 10 percent of construction workers have a bachelor's degree. The rest, 30 percent are high school graduates and 60 percent are elementary school graduates. So that from this reality, it is important for companies to manage and develop human resources. (Novianti, 2013).

This research is intended to identify and analyze the important factors of human resource management that affect labor productivity in construction projects in East Nusa Tenggara, and to determine the most dominant human resource management factors. It is hoped that this research can provide input to stakeholders, especially service users (project owners) and service providers (contractors and consultants) in East Nusa Tenggara so that they can identify, anticipate, reduce major risks that occur in construction projects in general.

\subsection{Research Purposes.}

The purpose of this study are as follows:

1. Knowing the human resource management factors that affect labor productivity in construction projects.

2. Knowing the human resource management factors that most dominantly affect labor productivity in construction projects

\subsection{Research Limitation and Scope}

Limitations and scope of this research are as follows:

1. This research is aimed only at the application of human resource management at the labor level (foremen, chief craftsmen, craftsmen).

2. This research is aimed at the implementation stage of a construction project. This is because workers are only involved in the implementation stage of a construction project.

3. This study took samples of all types of projects (building construction projects, water structures, bridge buildings, and pier buildings), without any restrictions on the types of projects. This is intended to take into account that there are no very significant differences between the characteristics of workers in various types of construction projects. 
4. This study limits the sampling locations to areas in eastern Indonesia, especially in East Nusa Tenggara.

\section{Material and Methods}

This research is using a survey method by collecting, formulating and processing data in the form of respondents' opinions, respondent attitudes regarding problems that exist in construction projects related to productivity, by taking primary data in the form of a questionnaire. The research was conducted in a normal situation that was not regulated (noncontrived settings) through a field study (field study) with minimal interference from researchers.

\subsection{Research Flow Method.}

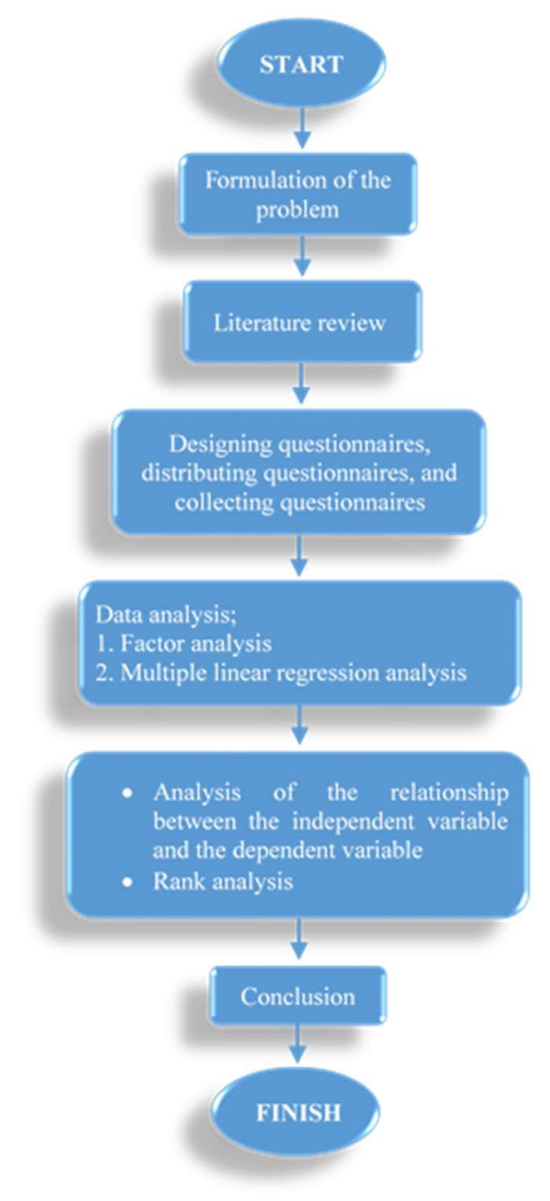

Figure 1. Research Flow Method.

\subsection{Research Flow Method.}

The location of this research was carried out on construction projects in East Nusa Tenggara which are spread over several districts, including Kupang Districts, South Central Timor Districts, North Central Timor Districts, East Flores Districts, Belu Districts.

\subsection{Research Population.}


The population of this study is labor at the contractor level including builders, head builders, foremen who are seen as having direct interactions with human resource management problems, the total number of respondents is 140 respondents. In addition to filling out questionnaires by respondents, direct interviews or by telephone with respondents were also conducted to clarify certain questions or answers. Thus it is expected to reduce bias that can arise due to differences in perceptions of the questions or scales used.

\subsection{Data Evaluation Techniques.}

The techniques for evaluating the data are as follows:

\section{A. Testing Item Instrument.}

In preparing the instrument test, before estimating the reliability and validity, the item analysis procedure is carried out first. Namely by testing the characteristics of each item that will be part of the test. Items which do not meet the quality requirements shall not be included as part of the test. Testing instrument item (item) in this study, used the SPSS tool, by looking at the corrected correlation (rc) obtained from the "corrected item-total correlation".

\section{B. Testing Instrument Validity.}

In this study, researchers measured the validity of the instrument using empirical validity. Namely, the researcher designed a research instrument, to determine its validity, the researcher then distributed the instrument to respondents who were not real respondents as many as 30 respondents. After being filled in by the respondents and collected again, the researcher then determined the validity of the SPSS program.

\section{Instrument Reliability Testing.}

Instrument reliability test is used to determine the consistency of the measuring instrument, in other words the measurement tool used is reliable and remains consistent if the measurement is repeated against the same group of subjects (homogeneous), as long as the aspects measured in the subject have not changed. Some of the reliability testing methods include retest method, Flanagan formula, Cronbach's Alpha, Anova Hoyt method. In this study, to test the reliability used the Cronbach's Alpha method. The calculation of reliability testing is carried out with the SPSS tool for all instrument items on the independent variable $\mathrm{X}$ and the dependent variable $\mathrm{Y}$, which are then tabulated in table form.

\section{Multiple Linear Regression Analysis.}

Testing using multiple linear regression analysis is intended to get answers; (1). The direction of the relationship between the independent variables (X1, X2, X3, X4, X5, X6, X7, X8, X9) on the dependent variable (Y), whether each independent variable has a positive or negative relationship. (2). Testing using multiple linear analysis is intended to predict the value of the dependent variable if the value of the independent variable has increased or decreased.

The general equation used for Multiple Linear Regression Analysis is:

$$
\mathrm{Y}=\mathrm{a}+(\mathrm{b} 1 \times \mathrm{X} 1)+(\mathrm{b} 2 \times \mathrm{X} 2) \ldots .+(\mathrm{bn} \times \mathrm{Xn})
$$

Description:

$\mathrm{Y}=$ dependent variable. In this study, the dependent variable is labor productivity (labor / builders).

$\mathrm{a}=$ is a constant value (intercept).

$\mathrm{Xn}=$ independent variable. In this study, the independent variables of review include:

1) Regarding Age. Denoted as X1.

2) Regarding Work Experience. Denoted as $X 2$. 
3) Regarding Education Level. Denoted as X3.

4) Regarding salary and conformity. Denoted as X4.

5) Regarding the number of dependents in the family. Denoted as X5.

6) Regarding Worker Health and Safety. Denoted as X6.

7) Concerning Relations Between Workers. Denoted as X7.

8) Regarding Managerial. Denoted as X8.

9) Regarding Motivation. Denoted as X9.

If the relationship between the independent variable and the dependent variable is depicted in a flowchart chart, it will be illustrated as shown below:

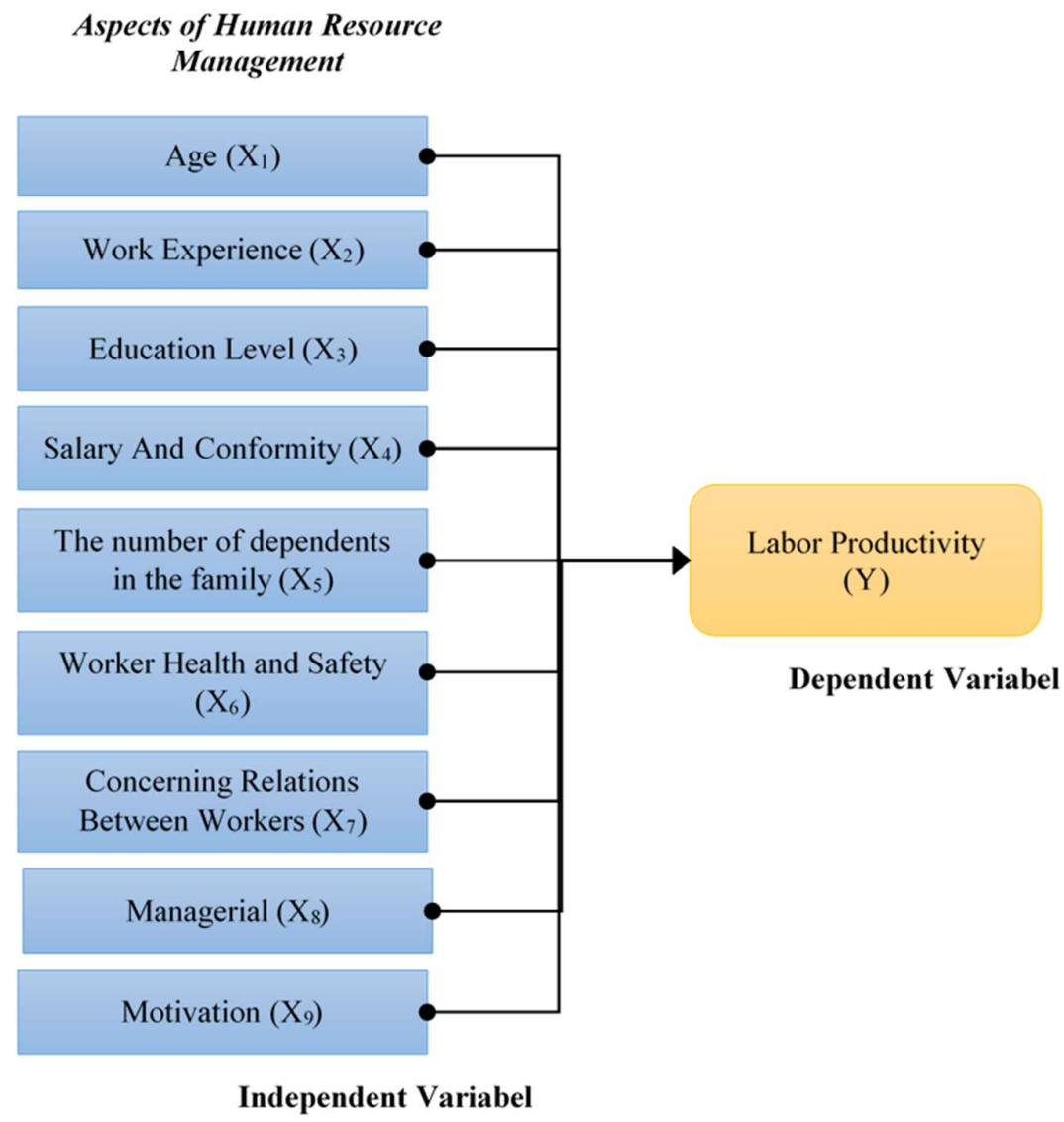

Figure 2. The scheme of the relationship between the independent variable and the dependent variable

\section{E. Classic assumption test.}

1. Normality Test

The purpose of the normality test is to test whether in a regression model, the dependent variable, the independent variable or both have a normal distribution or not.

2. Multicollinearity Test

Multicollinearity test is carried out to see if there is a perfect relationship between the independent variables. If in testing it turns out that a conclusion is obtained that the independent variables are interrelated, then the test cannot be carried out into the next stage 
because the variable regression coefficient cannot be determined and also the standard error value becomes infinite.

\section{F. Factor Analysis Method.}

The choice of factor analysis as an analysis tool in this study is because this study tries to find the relationship (interrelationship) of several variables that are independent of one another, so that a collection of variables that is smaller than the initial variable can be created so that it will be easier to control.

\section{Result and Discussion.}

\subsection{Research Instrument Test.}

\section{A. Item test.}

Table 1. Recapitulation of instrument item test results from each indicator variable $\mathrm{X}$ and from each indicator variable $\mathrm{Y}$

\begin{tabular}{|c|c|c|c|}
\hline \multicolumn{4}{|c|}{ DEPENDENT VARIABLE AITEM TEST, (X) } \\
\hline \multicolumn{2}{|c|}{ Variables Being Research Review } & \multirow{2}{*}{\begin{tabular}{|c|}
$\begin{array}{c}\text { Corrected Item-Total } \\
\text { Correlation }(\mathrm{rc})\end{array}$ \\
{$[3]$} \\
\end{tabular}} & \multirow{2}{*}{$\begin{array}{c}\text { Information } \\
{[4]} \\
\end{array}$} \\
\hline [I] & {$[2]$} & & \\
\hline \multirow{3}{*}{$\begin{array}{l}\text { Age } \\
{\left[\mathrm{X}_{1}\right]}\end{array}$} & $\mathrm{X}_{1.1}$ & 0,712 & Selected \\
\hline & $\mathrm{X}_{1.2}$ & 0,712 & Selected \\
\hline & $\mathrm{X}_{1.3}$ & 0,609 & Selected \\
\hline \multirow{3}{*}{$\begin{array}{c}\text { Work experience } \\
{\left[\mathrm{X}_{2}\right]}\end{array}$} & $\mathrm{X}_{2.1}$ & 0,657 & Selected \\
\hline & $\mathrm{X}_{2.2}$ & 0,657 & Selected \\
\hline & & & \\
\hline \multirow{3}{*}{$\begin{array}{l}\text { Level of educatio } \\
\qquad\left[\mathrm{X}_{3}\right] \\
\end{array}$} & $\mathrm{X}_{3.1}$ & 0,677 & Selected \\
\hline & $\mathrm{X}_{3.2}$ & 0,838 & Selected \\
\hline & $\mathrm{X}_{3.3}$ & 0,800 & Selected \\
\hline \multirow{4}{*}{$\begin{array}{l}\text { Salary and conformity } \\
\qquad\left[\mathrm{X}_{4}\right]\end{array}$} & $\mathrm{X}_{4.1}$ & 0,665 & Selected \\
\hline & $\mathrm{X}_{4.2}$ & 0,758 & Selected \\
\hline & $\mathrm{X}_{4.3}$ & 0,824 & Selected \\
\hline & $\mathrm{X}_{4.4}$ & 0,602 & Selected \\
\hline \multirow{3}{*}{$\begin{array}{l}\text { The number of dependents in- } \\
\text { the family } \\
{\left[\mathrm{X}_{5}\right]}\end{array}$} & $\mathrm{X}_{5.1}$ & 0,641 & Selected \\
\hline & $\mathrm{X}_{5.2}$ & 0,641 & Selected \\
\hline & & & \\
\hline \multirow{5}{*}{$\begin{array}{l}\text { Worker health and safety } \\
\qquad\left[\mathrm{X}_{6}\right]\end{array}$} & $\mathrm{X}_{6.1}$ & 0,677 & Selected \\
\hline & $\mathrm{X}_{6.2}$ & 0,868 & Selected \\
\hline & $\mathrm{X}_{6.3}$ & 0,660 & Selected \\
\hline & $\mathrm{X}_{6.4}$ & 0,823 & Selected \\
\hline & $\mathrm{X}_{6.5}$ & 0,812 & Selected \\
\hline \multirow{5}{*}{$\begin{array}{c}\text { Concerning relations } \\
\text { between workers } \\
{\left[\mathrm{X}_{7}\right]}\end{array}$} & $\mathrm{X}_{7.1}$ & 0,562 & Selected \\
\hline & $\mathrm{X}_{7.2}$ & 0,892 & Selected \\
\hline & $\mathrm{X}_{7.3}$ & 0,639 & Selected \\
\hline & $\mathrm{X}_{7.4}$ & 0,880 & Selected \\
\hline & $\mathrm{X}_{7.5}$ & 0,660 & Selected \\
\hline \multirow{4}{*}{$\begin{array}{l}\text { Managerial } \\
\qquad\left[\mathrm{X}_{8}\right]\end{array}$} & $\mathrm{X}_{8.1}$ & 0,671 & Selected \\
\hline & $\mathrm{X}_{8.2}$ & 0,741 & Selected \\
\hline & $\mathrm{X}_{8.3}$ & 0,826 & Selected \\
\hline & $\mathrm{X}_{8.4}$ & 0,592 & Selected \\
\hline \multirow{3}{*}{$\begin{array}{c}\text { Motivation } \\
{\left[\mathrm{X}_{9}\right]} \\
\end{array}$} & $\mathrm{X}_{9.1}$ & 0,459 & Selected \\
\hline & $\mathrm{X}_{9.2}$ & 0,698 & Selected \\
\hline & $\mathrm{X}_{9.3}$ & 0,706 & Selected \\
\hline
\end{tabular}

\begin{tabular}{|c|c|c|c|c|}
\hline \multicolumn{5}{|c|}{ INDEPENDENT VARIABLE AITEM TEST, (Y) } \\
\hline \multicolumn{3}{|c|}{ Variables Being Research Review } & Corrected Item-Total & Information \\
\hline [I] & [2] & {$[3]$} & {$[4]$} & {$[5]$} \\
\hline \multirow{17}{*}{$\begin{array}{c}\text { Productivity } \\
{[\mathrm{Y}]}\end{array}$} & \multirow{5}{*}{$\mathrm{Y}_{1}$} & $\mathrm{Y}_{1.1}$ & 0,682 & Selected \\
\hline & & $\mathrm{Y}_{1.2}$ & 0,854 & Selected \\
\hline & & $\mathrm{Y}_{1.3}$ & 0,495 & Selected \\
\hline & & $\mathrm{Y}_{1.4}$ & 0,762 & Selected \\
\hline & & $\mathrm{Y}_{1.5}$ & 0,738 & Selected \\
\hline & & & & \\
\hline & \multirow{5}{*}{$\mathrm{Y}_{2}$} & $\mathrm{Y}_{2.1}$ & 0,533 & Selected \\
\hline & & $\mathrm{Y}_{2.2}$ & 0,861 & Selected \\
\hline & & $\mathrm{Y}_{2.3}$ & 0,581 & Selected \\
\hline & & $\mathrm{Y}_{2.4}$ & 0,848 & Selected \\
\hline & & $\mathrm{Y}_{2.5}$ & 0,605 & Selected \\
\hline & & & & \\
\hline & \multirow{5}{*}{$\mathrm{Y}_{3}$} & $\mathrm{Y}_{3.1}$ & 0,779 & Selected \\
\hline & & $\mathrm{Y}_{3.2}$ & 0,554 & Selected \\
\hline & & $Y_{3.3}$ & 0,762 & Selected \\
\hline & & $\mathrm{Y}_{3.4}$ & 0,858 & Selected \\
\hline & & $\mathrm{Y}_{3.5}$ & 0,558 & Selected \\
\hline
\end{tabular}

Each indicator variable $\mathrm{X}$ and variable $\mathrm{Y}$ shows the amount of the corrected correlation value $(r c)$ obtained from the "corrected item-total correlation" greater than $30 \%\left(r c_{\text {CORECTION }} \geq 0,30\right)$, so it can be said that all selected instrument items are tested for validity and reliability testing. 


\section{B. Validity test.}

1. Keizer Meyer Olkin (KMO) and Bartlett test.

The Keizer Meyer Olkin (KMO) \& Bartlett test results obtained that the value of $9 \mathrm{X}$ variables is $\geq 0,5$. So it can be said that the variable $X$ can be broken down into a number of factors.

Table 2. KMO \& Bartlett Test Results

\begin{tabular}{|ll|c|}
\hline \multicolumn{1}{|c|}{ Variabel } & $\begin{array}{c}\text { KMO and } \\
\text { Bartlett's Test }\end{array}$ \\
\hline $\mathrm{X}_{1}$ Perihal Usia (age) & 0,703 \\
\hline $\mathrm{X}_{2}$ & Perihal Pengalaman Kerja (work experience) & 0,500 \\
\hline $\mathrm{X}_{3}$ & Perihal Tingkat Pendidikan (level of education) & 0,672 \\
\hline $\mathrm{X}_{4}$ & Perihal Gaji \& Kesesuaiannya (salary and conformity) & 0,713 \\
\hline $\mathrm{X}_{5}$ & Perihal Tanggungan Dalam Keluarga (dependents in the family) & 0,500 \\
\hline $\mathrm{X}_{6}$ & Perihal Kesehatan \& Keselamatan Kerja (occupational health and safety) & 0,799 \\
\hline $\mathrm{X}_{7}$ & Perihal Hubungan Antara Pekerja (working relationship between artisans) & 0,788 \\
\hline $\mathrm{X}_{8}$ & Perihal Manejerial(managerial) & 0,682 \\
\hline $\mathrm{X}_{9}$ & Perihal Motivasi (motivation) & 0,618 \\
\hline
\end{tabular}

2. Total Variance Explained.

Whereas of the 9 variables X has a cumulative "Extraction Sums of Squared Loadings" value $\geq 60 \%$, it can be said that the instrument item is "Valid" or can be used as a data collection tool.

Table 3. Total Variance Explained Results.

\begin{tabular}{|l|c|}
\hline \multicolumn{1}{|c|}{ Variabel } & $\begin{array}{c}\text { Extraction Sums Of } \\
\text { Squared Loading }\end{array}$ \\
\hline $\mathrm{X}_{1}$ Perihal Usia (age) & $60,830 \%$ \\
\hline $\mathrm{X}_{2}$ Perihal Pengalaman Kerja (work experience) & $65,639 \%$ \\
\hline $\mathrm{X}_{3}$ Perihal Tingkat Pendidikan (level of education) & $75,355 \%$ \\
\hline $\mathrm{X}_{4}$ Perihal Gaji \& Kesesuaiannya (salary and conformity) & $62,667 \%$ \\
\hline $\mathrm{X}_{5}$ Perihal Tanggungan Dalam Keluarga (dependents in the family) & $64,032 \%$ \\
\hline $\mathrm{X}_{6}$ Perihal Kesehatan \& Keselamatan Kerja (occupational health and safety) & $67,879 \%$ \\
\hline $\mathrm{X}_{7}$ Perihal Hubungan Antara Pekerja (working relationship between artisans) & $65,455 \%$ \\
\hline $\mathrm{X}_{8}$ Perihal Manejerial (managerial) & $61,627 \%$ \\
\hline $\mathrm{X}_{9}$ Perihal Motivasi (motivation) & $62,499 \%$ \\
\hline
\end{tabular}

\section{Reliability test.}

Reliability means "trustworthy" meaning, the instrument can give the right results. An instrument is categorized as reliable if it shows a constant measurement results and has a determination of the measurement results so that it is proven that the measuring instrument can really be justified. Table 4.shows the results of Cronbach's Alpa calculation on all $\mathrm{X}$ variables that have been tabulated. The value of " $\alpha$ " that occurs is $\geq 60 \%$. So it can be said that the research instrument is declared "reliable" and can be used as a data collection tool. 
Table 4. Reliability test Results

\begin{tabular}{|ll|c|}
\hline \multicolumn{1}{|c|}{ Variabel } & $\begin{array}{c}\text { Cronbach's } \\
\text { Alpha }\end{array}$ \\
\hline $\mathrm{X}_{1}$ Perihal Usia (age) & 0,814 \\
\hline $\mathrm{X}_{2}$ Perihal Pengalaman Kerja (work experience) & 0,793 \\
\hline $\mathrm{X}_{3}$ Perihal Tingkat Pendidikan (level of education) & 0,857 \\
\hline $\mathrm{X}_{4}$ Perihal Gaji \& Kesesuaiannya (salary and conformity) & 0,829 \\
\hline $\mathrm{X}_{5}$ Perihal Tanggungan Dalam Keluarga (dependents in the family) & 0,781 \\
\hline $\mathrm{X}_{6}$ Perihal Kesehatan \& Keselamatan Kerja (occupational health and safety) & 0,900 \\
\hline $\mathrm{X}_{7}$ Perihal Hubungan Antara Pekerja (working relationship between artisans) & 0,861 \\
\hline $\mathrm{X}_{8}$ Perihal Manejerial (managerial) & 0,850 \\
\hline $\mathrm{X}_{9}$ Perihal Motivasi (motivation) & 0,762 \\
\hline
\end{tabular}

\subsection{Multiple Linear Regression Analysis.}

The regression model equation between Productivity (Y) on aspects of human resources Regarding Age (X1), Regarding Work Experience (X2), Regarding Education Level (X3), Regarding Salary and conformity (X4), Regarding the Number of Dependents in the Family (X5), Regarding Health and Worker Safety (X6), Regarding Relationships Between Workers (X7), Regarding Managerials (X8), Concerning Motivation (X9) were carried out with the SPSS assistance program, the results of which were as follows:

Table 5. Regression model coefficients

\begin{tabular}{|c|c|c|c|c|c|c|}
\hline & \multirow[t]{2}{*}{ Model } & \multicolumn{2}{|c|}{$\begin{array}{l}\text { Unstandardized } \\
\text { Coefficients }\end{array}$} & \multirow{2}{*}{$\begin{array}{c}\begin{array}{c}\text { Standardized } \\
\text { Coefficients }\end{array} \\
\text { Beta }\end{array}$} & \multirow[t]{2}{*}{$\mathrm{t}$} & \multirow[t]{2}{*}{ Sig. } \\
\hline & & B & Std. Error & & & \\
\hline \multirow{10}{*}{1} & (Constant) & 12,776 & 1,367 & & 9,343 & .000 \\
\hline & $\mathrm{X} 1$ &,- 217 & 149 & - 120 & $-1,455$ & .014 \\
\hline & $\mathrm{X} 2$ & 151 & , 105 &, 115 & 1,439 & .015 \\
\hline & $\mathrm{X} 3$ & ,087 & 166 & ,043 & ,521 & ,006 \\
\hline & $\times 4$ & , 074 & 143 &, 045 &, 517 &, 006 \\
\hline & $\times 5$ &,- 263 & , 117 &,- 186 & $-2,252$ & .026 \\
\hline & $\mathrm{X} 6$ &, 468 & , 130 &, 289 & 3,601 & .000 \\
\hline & $\mathrm{X} 7$ &, 058 &, 173 &, 029 & ,333 & .007 \\
\hline & $\mathrm{X} 8$ & , 129 & , 146 & , 072 & ,883 & .037 \\
\hline & $\times 9$ & , 384 & , 169 & , 196 & 2,276 & .024 \\
\hline
\end{tabular}

From the table above, the regression equation is obtained as follows:

$$
\begin{aligned}
\widehat{\mathrm{Y}}= & 12,776-0,217 \mathrm{X}_{1}+0,151 \mathrm{X}_{2}+0,087 \mathrm{X}_{3}+0,074 \mathrm{X}_{4}-0,263 \mathrm{X}_{5}+0,468 \mathrm{X}_{6}+ \\
& +0,058 \mathrm{X}_{7}+0,129 \mathrm{X}_{8}+0,384 \mathrm{X}_{9}
\end{aligned}
$$




\subsection{Multicollinearity Test.}

Table 6. The results of the multicollinearity test for the independent variable

\begin{tabular}{|c|c|c|c|c|c|c|c|c|}
\hline & \multirow{2}{*}{ Model } & \multicolumn{2}{|c|}{$\begin{array}{l}\text { Unstandardized } \\
\text { Coefficients }\end{array}$} & \multirow{2}{*}{$\begin{array}{c}\text { Standardized } \\
\text { Coefficients } \\
\text { Beta }\end{array}$} & \multirow[t]{2}{*}{$t$} & \multirow{2}{*}{ Sig. } & \multicolumn{2}{|c|}{$\begin{array}{c}\text { Collinearity } \\
\text { Statistics }\end{array}$} \\
\hline & & B & Std. Error & & & & Tolerance & VIF \\
\hline \multirow{10}{*}{1} & (Constant) & 12,776 & 1,367 & & 9,343 & ,000 & & \\
\hline & $\mathrm{X}_{1}$ &,- 217 &, 149 &,- 120 & $-1,455$ &, 014 & 903, & 1,107 \\
\hline & $X 2$ &, 151 & , 105 & , 115 & 1,439 & 015 & ,958 & 1,044 \\
\hline & $\mathrm{X} 3$ &, 087 & , 166 &, 043 &, 521 & ,006 & ,909 & 1,101 \\
\hline & $\mathrm{X} 4$ & ,074 & , 143 &, 045 &, 517 &, 006 &, 818 & 1,223 \\
\hline & $\times 5$ &,- 263 & , 117 &,- 186 & $-2,252$ & ,026 & ,900 & 1,111 \\
\hline & $x_{6}$ &, 468 & , 130 &, 289 & 3,601 & , 000 & ,953 & 1,050 \\
\hline & $x 7$ &, 058 & , 173 & ,029 & ,333 & ,007 & ,829 & 1,207 \\
\hline & $\mathrm{X} 8$ & , 129 & , 146 & ,072 & ,883 & ,037 & ,929 & 1,076 \\
\hline & X9 & ,384 & 169, & 196 & 2,276 &, 024 &, 829 & 1,206 \\
\hline
\end{tabular}

The results of calculations using the SPSS program which can be seen in table 6, explain that the VIF value generated from each variable $(\mathrm{X} 1, \mathrm{X} 2 \ldots \mathrm{X} 9)$ is below the number $10(\mathrm{VIF}<10)$, so it can be said that the review variables $(\mathrm{X} 1, \mathrm{X} 2) \ldots \mathrm{X} 9)$ does not experience multicollinearity and regression analysis can be performed.

\subsection{Heteroscedasticity Test.}

Based on Figure 3, it can be explained that the distribution of the residual value is spread around the zero ( 0 ) value, so it can be said that the residual variance value from one observation to another is the same. In other words, the data come from the same distribution and there is no significant difference.

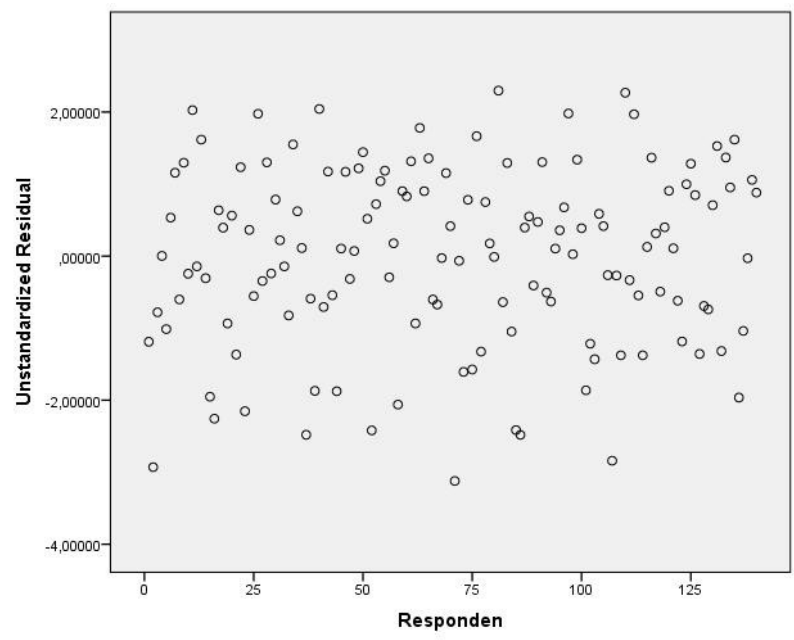

Figure 3. Residual scatter diagram. 


\subsection{Autocorrelation Test.}

Autocorrelation test analysis is intended to obtain a correlation between the observed values in the dependent variable (autocorrelation), by performing the Durbin-Watson test. Determine the test hypothesis :

H0: $\rho=0 \Rightarrow$ It means that the value of the observed data does not occur autocorrelation (random). H1: $\rho>0 \Rightarrow$ It means that the value of the observed data occurs autocorrelation (not random).

Table 7. Durbin-Watson Test Results

\begin{tabular}{|c|c|c|c|c|c|}
\multicolumn{1}{c|}{ Model Summarx } \\
\hline & $\mathrm{R}$ & $\begin{array}{c}\mathrm{R} \\
\text { Model }\end{array}$ & $\begin{array}{c}\text { Adjusted } \\
\mathrm{R} \\
\text { Square }\end{array}$ & $\begin{array}{c}\text { Std. Error } \\
\text { of the } \\
\text { Estimate }\end{array}$ & $\begin{array}{c}\text { Durbin- } \\
\text { Watson }\end{array}$ \\
\hline 1 & $.447^{3}$ & .800 & .744 & 1.40284 & 1.945 \\
\hline
\end{tabular}

a. Predictors: (Constant), X9, X3, X2, X1, X6, X8, X5, X7, X4

b. Dependent Variable: $Y$

Based on the results of the analysis shown in table 8 , it shows that the value of DW $=1,945$, then $\mathrm{H} 0$ is accepted, which means that the observational data does not occur autocorrelation (random).

\subsection{Multiple Linear Regression Model Test Analysis.}

Determine the test hypothesis:

H0 : NO INFLUENCE on aspects of human resources, in this case the age (X1), work experience (X2), education level (X3), salary and conformity (X4), the number of dependents in the family (X5), health And Worker Safety (X6), Relationships Between Workers (X7), Managerials (X8), Concerning Motivation (X9) on Labor Productivity (Y).

H1 : THERE IS AN INFLUENCE regarding aspects of human resources, in this case the age (X1), work experience (X2), education level (X3), salary and conformity (X4), the number of dependents in the family (X5), health And Worker Safety (X6), Relationships Between Workers (X7), Managerials (X8), Concerning Motivation (X9) on Labor Productivity (Y).

Table 8. Results of the analysis of variance in the regression model

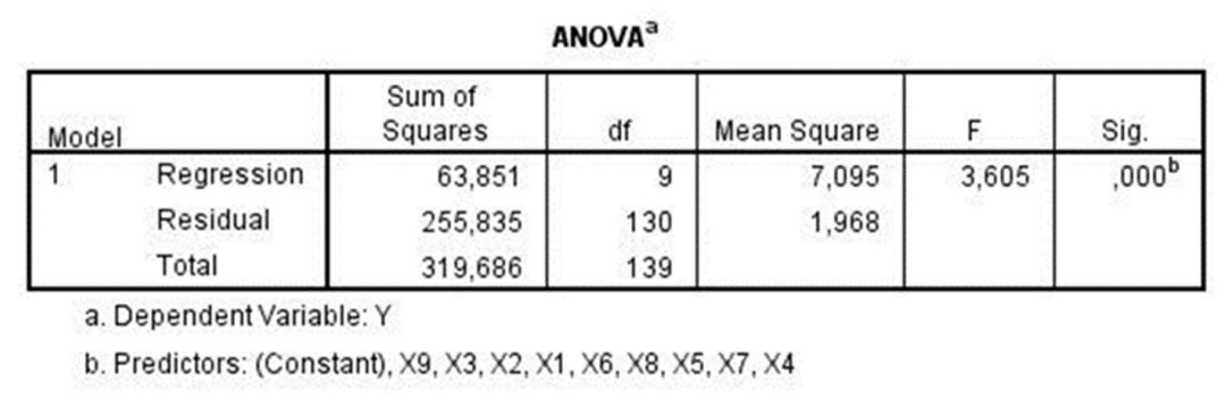

The table can be explained as follows:

a) sig value. $=0,00<\alpha=0,05$ So it can be concluded that the null hypothesis (H0) is rejected and hypothesis one (H1) is accepted, so it can be said that there is a relationship of influence between 
variable $\mathrm{X}$ on $\mathrm{Y}$. in this case variable $\mathrm{X}$ talks about Age (X1), Regarding Work Experience (X2), Regarding Education Level (X3), Regarding salary and conformity (X4), Regarding the Number of Dependents in the Family (X5), Regarding Workers' Health and Safety (X6), Regarding Relationships between Workers (X7), Regarding Managerial (X8), Regarding Motivation (X9) on Variable Y talking about Labor Productivity.

b) Sig. $=0.00<0.05$, it means that the regression equation as mentioned above is acceptable.

c) The value of $\mathrm{F}_{\text {Hitung }}=3,605$. While the degree of freedom (df) for respondents was $140(\mathrm{~N} 2=$ 140), $\mathrm{N} 1=9$, the significant level was $\alpha=0,05$. Resulting in $\mathrm{F}_{\mathrm{TABEL}}=1,95\left(\mathrm{~F}_{\text {Hitung }}=3,605>\right.$ $\mathrm{F}_{\text {Tabel }}=1,95$ ). It can be concluded that there is a significant influence simultaneously between $\mathrm{X} 1, \mathrm{X} 2, \mathrm{X} 3, \mathrm{X} 4, \mathrm{X} 5, \mathrm{X} 6, \mathrm{X} 7, \mathrm{X} 8, \mathrm{X} 9$ on $\mathrm{Y}$

\subsection{Coefficient of Determination.}

The calculation of the coefficient of determination is obtained using the SPSS program as follows:

Table 9. The results of the analysis of the coefficient of determination

Model Summary

\begin{tabular}{|l|r|r|r|r|r|}
\hline Model & R & R Square & $\begin{array}{c}\text { Adjusted R } \\
\text { Square }\end{array}$ & $\begin{array}{c}\text { Std. Error of the } \\
\text { Estimate }\end{array}$ & Durbin-Watson \\
\hline 1 &, $447^{3}$ &, 800 &, 744 & 1,40284 & 1,945 \\
\hline
\end{tabular}

a. Predictors: (Constant), X9, X3, X2, X1, X6, X8, X5, X7, X4

b. Dependent Variable: $Y$

$\mathrm{R} 2$ value $=0,800$. This value implies that the previously calculated regression model can explain the positive relationship simultaneously (simultaneously) between the $\mathrm{X}$ variable which talks about Age (X1), Regarding Work Experience (X2), Regarding Education Level (X3), Regarding salary and conformity (X4), Regarding the Number of Dependents in the Family (X5), Regarding Worker Health and Safety (X6), Concerning the Relationship Between Workers (X7), Regarding Managerials (X8), Regarding Motivation (X9) Against Variable Y which talks about Labor Productivity is $80 \%$ while the remaining $20 \%$ is the influence of other independent variables that are not found in the previously calculated regression model or equation. Standard error of estimate (SEE) is 1,402. The smaller the SEE will make the regression model more precise in predicting the dependent variable.

\subsection{Residual Data Normal Distribution Test.}

From Figure 4, shows the plot of the residual value following a straight line in an increasing direction, so it can be concluded that the residual data is normally distributed. 


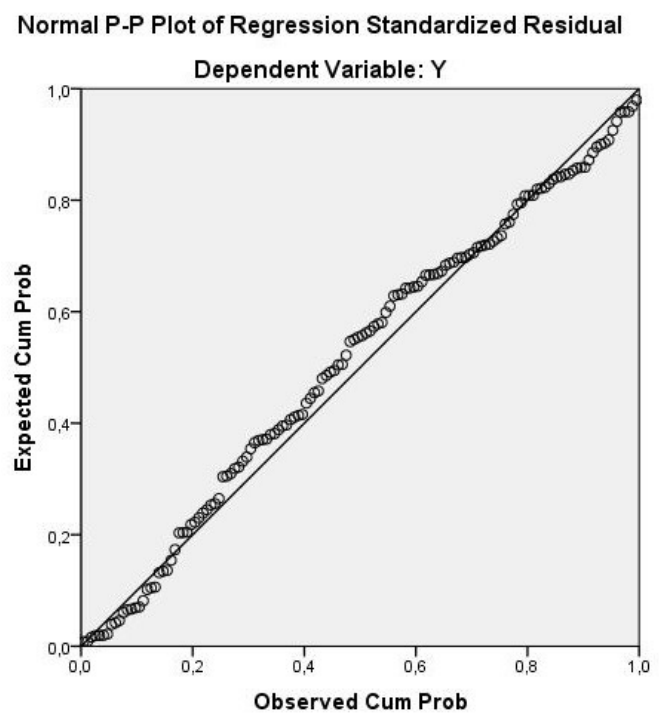

Figure 4. Graph of normal residual data plots.

\subsection{Independent Variable Dominant Analysis.}

Determination of the factors that affect the variable $\mathrm{Y}$ is by using the "stepwise regression" method. The results are shown as follows:

Table 4.11. Regression equation coefficients

\begin{tabular}{|c|c|c|c|}
\hline Model & $\begin{array}{c}\text { Variables } \\
\text { Entered }\end{array}$ & $\begin{array}{l}\text { Variables } \\
\text { Removed }\end{array}$ & Method \\
\hline 2 & $\begin{array}{l}\times 5 \\
\times 9\end{array}$ & . & $\begin{array}{l}\text { Stepwise (Criteria: Probability-of-F-to-enter }<\bar{m} \\
.050, \text { Probability-of-F-to-remove }>=, 100 \text { ). } \\
\text { Stepwise (Criteria: Probability-of-F-to-enter }<\overline{=} \\
.050, \text { Probability-of-F-to-remove }>=, 100 \text { ). } \\
\text { Stepwise (Criteria: Probability-of-F-to-enter }<\overline{=} \\
, 050, \text { Probability-of-F-to-remove }>=, 100 \text { ). }\end{array}$ \\
\hline
\end{tabular}

a. Dependent Variable: $Y$

\begin{tabular}{|c|c|c|c|c|c|c|}
\hline & \multirow[t]{2}{*}{ Model } & \multicolumn{2}{|c|}{$\begin{array}{l}\text { Unstandardized } \\
\text { Coefficients }\end{array}$} & \multirow{2}{*}{$\begin{array}{c}\begin{array}{c}\text { Standardized } \\
\text { Coefficients }\end{array} \\
\text { Beta }\end{array}$} & \multirow[t]{2}{*}{$\mathrm{t}$} & \multirow[t]{2}{*}{ Sig. } \\
\hline & & B & Std. Error & & & \\
\hline \multirow{2}{*}{1} & (Constant) & 12,554 &, 496 & & 25,294 &, 000 \\
\hline & $\begin{array}{l}\mathrm{X} 6 \\
\text { (Constant) }\end{array}$ & $\begin{array}{r}13,462 \\
13,292\end{array}$ & - & ,286 & $\begin{array}{r}3,500 \\
24,562\end{array}$ & , 000 \\
\hline 2 & $\begin{array}{l}X 6 \\
X 5 \\
\text { (Constant) }\end{array}$ & $\begin{array}{r}, 429 \\
-, 338 \\
12,497\end{array}$ & $\begin{array}{l}, 129 \\
, 112 \\
, 656\end{array}$ & $\begin{array}{r}, 265 \\
-, 239\end{array}$ & $\begin{array}{r}3,335 \\
-3,009 \\
19,037\end{array}$ & $\begin{array}{l}000 \\
.003 \\
, 000\end{array}$ \\
\hline \multirow{3}{*}{3} & $x 6$ &, 462 & , 128 &, 286 & 3,606 &, 000 \\
\hline & $\times 5$ &,- 282 & , 114 &,- 200 & $-2,478$ & 014 \\
\hline & $\times 9$ & .330 & 158 & 169 & 2,086 & .039 \\
\hline
\end{tabular}

Model 1 : The constant coefficient, $a$ is 12,554 and the regression coefficient (X6 - Regarding Worker Health \& Safety) $b_{1}$ is 0,462 , thus forming the equation:

$$
\widehat{Y}=12,554+0,462 X_{6}
$$


Model 2 : The constant coefficient, $a$ is 13,292 and the regression coefficient (X6 - Regarding Worker Health \& Safety) $b_{1}$ is 0,429 and the regression coefficient (X5 - Regarding the Number of Dependents in the Family) $b_{2}$ is $-0,338$ thus forming the equation:

$$
\widehat{Y}=12,554+0,429 \mathrm{X}_{6}-0,338 \mathrm{X}_{5}
$$

Model 3 : The constant coefficient, $a$ is 12,497 and the regression coefficient (X6 - Regarding Worker Health \& Safety) $b_{1}$ is 0,462 and the regression coefficient (X5 - Regarding Number of Dependents in the Family) $b_{2}$ is $-0,282$ and the regression coefficient (X9Regarding Motivation) $b_{3}$ is 0,330 . So that it forms the equation:

$$
\widehat{Y}=12,554+0,462 X_{6}-0,282 X_{5}+0,330 X_{9}
$$

Thus, the best model which states the relationship of variable $\mathrm{X}$ to variable $\mathrm{Y}$ (labor productivity) is in equation (5), and contains the following meanings:

1) Regression coefficient $b_{1}=+0,462$ (positive). This means that the $X 6$ variable has a proportional relationship to the Y variable. In another sense, if "Worker Health \& Safety" is given special attention by increasing the health and safety level of workers (craftsmen / laborers), the productivity value to be achieved will increase.

2) Regression coefficient $b_{2}=-0,282$ (negative). This means that the variable $X 5$ does not have a directly proportional relationship to variable Y. In another sense, if the "Number of Dependents in the Family" decreases or does not have the number of dependents in the family, the productivity value to be achieved will increase.

3) Regression coefficient $b_{3}=+0,330$ (positive). This means that the $X 9$ variable has a directly proportional relationship to the $\mathrm{Y}$ variable.In another sense, if the "motivation" for workers (craftsmen / laborers) is increased, the productivity value to be achieved will increase.

\section{Conclusions}

The results of data processing and data discussion is a process to obtain a form of conclusion that answers the objectives of this study. The conclusions obtained are as follows:

a) Human Resource Management factors in several construction projects in East Nusa Tenggara which include 9 aspects (Age, Work Experience, Education Level, Salary and Conformity, Number of Dependents in the Family, Worker Health and Safety, Inter-Employee Relations, Managerial, Motivation) greatly affect productivity improvement. construction workforce, with an influence value of $80 \%$, while the remaining $20 \%$ is influenced by other factors outside the model.

b) Human Resource Management factors that are dominant in influencing labor productivity on construction projects in East Nusa Tenggara are respectively Worker Health \& Safety (X6), Number of Dependents in the Family (X5), and Regarding Motivation (X9). With the following understanding:

- If "Worker Health \& Safety" is given special attention by increasing the health and safety level of workers (craftsmen / laborers), the productivity value to be achieved will increase.

- If the "Number of Dependents in the Family" decreases or does not exist at all, then the productivity value to be achieved will increase.

- If the "motivation" towards workers (craftsmen / laborers) is increased, the productivity value to be achieved will increase.

\section{Suggestion:}

1. Service providers, in this case contractors and consultants in East Nusa Tenggara, must immediately respond to several important points in terms of human resource management, including the following factors: Regarding Worker Health \& Safety, Regarding Number of 
Dependents in the Family, and Regarding Motivation. So that what is a problem in improving labor productivity can be resolved properly

2. Future research should use human resource factors that are more focused on Worker Health \& Safety.

3. Future research is expected to test a sample of more than 140 respondents and spread across all districts in East Nusa Tenggara

\section{Acknowledgements}

The author would like to thank Dr. Ir. H. Sri Wiwoho Mudjanarko ST., MT., IPM, Narotama University Civil Engineering Lecturer as the supervisor and Ir. Hary Moetriono, M.Sc, Lecturer in Civil Engineering, University of 17 August 1945 for his support in insightful and constructive comments.

\section{References}

[1] A. A. D. Paramani Dewi, Analisis Aspek Sumber Daya Manusia Terhadap Kinerja Pada Proyek Konstruksi Di Kabupaten Badung, Jurnal Ilmiah Teknik Sipil : a scientific journal of civil engineering, Vol. 20, No. 2, Juli 2016.

[2] Ardana, I Komang dkk, Manajemen Sumber Daya Manusia, Graha Ilmu, Yogyakarta 2012.

[3] Armstrong, Michael, Strategic Human Resource Management. Koganpage, London and Philadelphia, 2000.

[4] Bhanthara, R., Mudjanarko, S. W., \& Moetriono, H., Study Of Factors Causing Delay Of Completion Of Construction Work Building In Airlangga University Surabaya. INSCIENTECH: Journal of Industrial Science and Technology, ISSN 2598-3113, 2017.

[5] B. Burhan, Analisis Data Penelitian Kualitatif, Rajawali Perss Jakarta, 2003.

[6] C. Chandra, Pengaruh Pengalaman dan Karakter Sumber Daya Manusia Konsultan Manajemen Konstruksi Terhadap Kualitas Pekerjaan Pada Proyek Di Kabuoaten Pandegelang, Jurnal Teknik Sipil Universitas Sultan Ageng Tritayasa, Vol. 7 No.1, 2018.

[7] Campbell, R. McConnell and Stanley L. Brue, Economics: Principles, Problems and Policies. McGraw-Hill Publishing Company, 1990.

[8] Cleland, D.I and King, W.R, Project Management Hand Book, Second Edition, Van Nostrand Reinhold, 1993.

[9] Cornelius, Trihendardi, Step by Step SPSS 13, Analisis Data Statistik, 2005.

[10] Ervianto, I. Wulfram, Manajemen Proyek Konstruksi, Yogyakarta, 2002.

[11] George, R. Terry, Prinsip - Prinsip Manajemen, Jakarta, 2006.

[12] G. Imam, Aplikasi Analisis Multivariate dengan SPSS, Semarang, 2005.

[13] I. Dipohusodo, Manajemen Proyek dan Konstruksi jilid 1 dan 2, Kanisius, Jakarta, 1996.

[14] Janie, N. D. Arum, Statistik Deskriptif \& Regresi Linear Berganda Dengan SPSS, Semarang University Press, 2012.

[15] Kaming, F. Peter, Productivity Problems Encounted By Indonesian Construction Foreman, The $3^{\text {rd }}$ International Conference of EACEF, September 20-22, 2011

[16] Kurniawan, Fredy, Sri Wiwoho Mudjanarko, and Stephen Ogunlana, Best Parctice for Financial Models of PPP Projects. The $5^{\text {th }}$ international Conference of Euro Asia Civil Engineering Forum (EACEF-5) : 124-32 Elsevier, 2015.

[17] L. A. Eric \& S. Augustinus, Pengelolaan Dan Pengembangan Sumber Daya Manusia Pada PT. Aneka Sejahtera Engineering, Jurnal Manajemen Bisnis PETRA, Vol. 1 No. 2, 2013.

[18] M. Andi \& A. Rahman, Pengaruh Pengalaman Kerja Dan Gaya Kepemiminan Terhadap Kinerja Sumber Daya Manusia (SDM) Konstruksi, Jurnal Konstruksia Vol. 8 No. 1, Desember 2016.

[19] Matondang Zulkifli, Validitas dan Reliabilitas Suatu Instrument. Jurnal Tabularasa PPS UNIMED, Vol 6, No. 1, 2009.

[20] Mulyadi, L, dkk. Evaluasi Pengaruh Kinerja Mandor Terhadap Kualitas Pekerjaan Pembangunan Gedung. Jurnal Informasi Manajemen Proyek, Vol. 1, 2014. 


\section{JICEJournal Innovation of Civil Engineering}

Vol. 1, No. 1, pp. 32-45, 2020

Submit: $10-03-2020$

Accepted: 22-04-2020 |

Publish: 24-04-2020 |

[21] N. Nasron \& A. T. Bodro, Faktor-Faktor Yang Mempengaruhi Produktivitas Kerja (Studi Pada Karyawan Bagian Produksi PT Mazuvo Indo). Jurnal Akutansi dan Bisnis STIE Widya Manggala. 2012.

[22] Novianti. L, Manajemen dan Pengembangan Sumber Daya Manusia Pada Jasa Konstruksi PT. CDE Jawa Timur. Jurnal Manajemen Bisnis Universitas Kristen Petra, Vol. 1 No. 1, 2013.

[23] Sukawi, Peran Analisis Regresi Berganda Dalam Penelitian Survey Deskriptif, Jurnal Seminar Nasional "Metodologi Riset dalam Arsitektur", Denpasar, Juni 2010.

[24] Suprapta. Made, Pengaruh Kepemimpinan Terhadap Kepuasan Kerja Dan Kinerja Karyawan. E-Jurnal Ekonomi dan Bisnis Universitas Udayana 4.06, pp. 430-442, 2015.

[25] Werther, William B. \& Keith Davis, Human Resources And Personal Management. International Edition. McGraw-Hiil, Inc., USA, 1996.

[27] Williams, Raymond, Keyword: A Vocabulary of Culture and Society. London: Fontana, 1983.

[28] Wirawan, Evaluasi Kinerja Sumber Daya Manusia Teori Aplikasi dan Penelitian. Penerbit: Salemba Empat, Jakarta, 2009. 